Article

\title{
Terrestrial CDOM in Lakes of Yamal Peninsula: Connection to Lake and Lake Catchment Properties
}

\author{
Yury Dvornikov 1,2,*(D), Marina Leibman 1,3 (D), Birgit Heim 2 (D), Annett Bartsch 4,5,6, \\ Ulrike Herzschuh $^{2,7}$, Tatiana Skorospekhova ${ }^{8}$, Irina Fedorova 9,10, Artem Khomutov 1,3 (DD, \\ Barbara Widhalm ${ }^{5}$, Anatoly Gubarkov ${ }^{11}$ and Sebastian Rößler ${ }^{12}$ \\ 1 Earth Cryosphere Institute Tyumen Scientific Centre SB RAS, 625026 Tyumen, Russia; \\ moleibman@gmail.com (M.L.); akhomutov@gmail.com (A.K.) \\ 2 Alfred Wegener Institute Helmholtz Centre for Polar and Marine Research, 14473 Potsdam, Germany; \\ birgit.heim@awi.de (B.H.); ulrike.herzschuh@awi.de (U.H.) \\ 3 University of Tyumen, International Institute of Cryology and Cryosophy, 625003 Tyumen, Russia \\ 4 b.geos, 2100 Korneuburg, Austria; annett.bartsch@bgeos.com \\ 5 Zentralanstalt für Meteorologie und Geodynamik, 1190 Vienna, Austria; Barbara.Widhalm@zamg.ac.at \\ 6 Austrian Polar Research Institute, 1090 Vienna, Austria \\ 7 Institute of Earth and Environmental Sciences, University of Potsdam, 14469 Potsdam, Germany \\ 8 Arctic and Antarctic Research Institute, 199397 Saint-Petersburg, Russia; tanchiz@gmail.com \\ 9 Institute of Earth Science, Saint-Petersburg State University, 199178 Saint-Petersburg, Russia; \\ umnichka@mail.ru \\ 10 Kazan Federal University, 420008 Kazan, Russia \\ 11 Tyumen Industrial University, 625000 Tyumen, Russia; agubarkov@gmail.com \\ 12 FIELAX, 27568 Bremerhaven, Germany; roessler@fielax.de \\ * Correspondence: ydvornikow@gmail.com; Tel.: +7-985-287-9220
}

Received: 7 November 2017; Accepted: 20 January 2018; Published: 25 January 2018

\begin{abstract}
In this study, we analyze interactions in lake and lake catchment systems of a continuous permafrost area. We assessed colored dissolved organic matter (CDOM) absorption at $440 \mathrm{~nm}$ $\left(\mathrm{a}(440)_{\mathrm{CDOM}}\right)$ and absorption slope $\left(\mathrm{S}_{300-500}\right)$ in lakes using field sampling and optical remote sensing data for an area of $350 \mathrm{~km}^{2}$ in Central Yamal, Siberia. Applying a CDOM algorithm (ratio of green and red band reflectance) for two high spatial resolution multispectral GeoEye-1 and Worldview-2 satellite images, we were able to extrapolate the $\mathrm{a}(\lambda)_{\mathrm{CDOM}}$ data from 18 lakes sampled in the field to 356 lakes in the study area (model $R^{2}=0.79$ ). Values of a $(440)_{\mathrm{CDOM}}$ in 356 lakes varied from 0.48 to $8.35 \mathrm{~m}^{-1}$ with a median of $1.43 \mathrm{~m}^{-1}$. This a $(\lambda)_{\mathrm{CDOM}}$ dataset was used to relate lake CDOM to 17 lake and lake catchment parameters derived from optical and radar remote sensing data and from digital elevation model analysis in order to establish the parameters controlling CDOM in lakes on the Yamal Peninsula. Regression tree model and boosted regression tree analysis showed that the activity of cryogenic processes (thermocirques) in the lake shores and lake water level were the two most important controls, explaining $48.4 \%$ and $28.4 \%$ of lake CDOM, respectively $\left(R^{2}=0.61\right)$. Activation of thermocirques led to a large input of terrestrial organic matter and sediments from catchments and thawed permafrost to lakes $\left(n=15\right.$, mean $\left.\mathrm{a}(440)_{\mathrm{CDOM}}=5.3 \mathrm{~m}^{-1}\right)$. Large lakes on the floodplain with a connection to Mordy-Yakha River received more CDOM $\left(n=7\right.$, mean a $\left.(440)_{\mathrm{CDOM}}=3.8 \mathrm{~m}^{-1}\right)$ compared to lakes located on higher terraces.
\end{abstract}

Keywords: CDOM; lakes; lake catchments; permafrost; Yamal; remote sensing data

\section{Introduction}

The high latitude Arctic lowlands underlain by permafrost are particularly rich in lakes [1-3]. Most of these lakes are of thermokarst origin [4] and represent carbon turnover hotspots [5]. Both 
the photodegradation of lake organic matter [6] and subsequent biodegradation processes lead to the formation and outgassing of methane $[7,8]$. Compared with the allochthonous component of Arctic lakes, the autochthonous component, i.e., plankton, is assumed to play a small role in the total organic matter content $[9,10]$.

Dissolved organic content of lake water influences the penetration depth of ultra-violet and visible sunlight [11-14]. High organic matter concentration can increase the absorption of light in lakes which may warm the water body and impacts the energy balance of high-latitude landscapes [13]. Organic matter in lakes is also assumed to influence lake biodiversity [12].

The dissolved organic content in lake water is known to decrease along a vegetation biomass gradient south to north from the boreal forest to arctic tundra [12,15-17]. This reflects the fact that the surrounding lake catchments are the main source of the dissolved organic matter in inland waters $[9,10,12,15,16]$. However, the large-scale trend over the vegetation biomass/latitude gradient is overlain by high small-scale spatial variability, the origin of which is not yet fully understood [18].

Ongoing Arctic warming is changing Arctic landscapes in various ways that potentially alter the organic matter supply to lakes. Warming may increase vegetation density in lake catchments and in turn the organic matter supply to lakes. Furthermore, warming may cause an increase of ground temperatures [19] and a deepening of the active layer (the annually-thawed upper soil layer) [20] in permafrost soils and thus activate various cryogenic processes including thermodenudation [21,22] in the lake shores, leading to changes of the geochemistry and organic matter content in those lakes [23,24].

The total organic matter in lake water can be separated into particulate organic matter (POM) and dissolved organic matter (DOM). POM is the organic fraction of suspended particulate matter including the phytoplankton and detritus. The colored dissolved organic matter (CDOM) is the colored fraction of dissolved organic carbon (DOC) and is highly correlated to DOC concentration over a wide range of aquatic ecosystems [25,26]. CDOM mainly consists of fulvic and humic acids [9], absorbing in the short wavelength ranges. CDOM is typically measured photometrically after filtration where the parameters obtained are absorption at a specific wavelength $(\lambda)$ and the spectral slope coefficient, $(S)$ denoting the steepness of the absorption spectra, providing information on both CDOM concentration and CDOM type, respectively [27-30].

Here, we study CDOM in lakes of Central Yamal in the Russian Arctic as derived from field sampling and calculated with a CDOM algorithm using optical satellite data. We relate these data to a number of environmental variables characterizing the lake's internal characteristics and catchment properties. We address the following research questions: (1) What is the range of CDOM in lakes of Central Yamal? (2) Which catchment characteristics and lake properties explain the variations in CDOM absorption and slope values?

\section{Study Area}

The study region comprises a $350 \mathrm{~km}^{2}$ area in the central part of the Yamal Peninsula (West Siberia) located around the long-term Russian research station Vaskiny Dachi $\left(70^{\circ} 20^{\prime} \mathrm{N}, 68^{\circ} 51^{\prime} \mathrm{E}\right)$ (Figure 1) [31]. Vaskiny Dachi was established in 1988 as a permafrost monitoring site, and since 1996 it has been operated by the Earth Cryosphere Institute, Siberian Branch of the Russian Academy of Sciences. The area is also an established site for the international Global Terrestrial Network for Permafrost (GTN-P) program [31].

More than 350 water bodies with an area greater than $1000 \mathrm{~m}^{2}$ are located within the study area resulting in approximately $12 \%$ limnicity. The central part of the studied region is characterized by elevated terraces which are extensively dissected by narrow valleys of rivers, small streams, gullies, and ravines. There are several geomorphological terraces consisting of Quaternary marine sediments comprised of sands, loam, and clays overlain by organic layer. The large floodplains of the Se-Yakha and Mordy-Yakha Rivers are located in the southwest and northwest of the study area, respectively. On the floodplains, lakes undergo considerable flooding in early summer and are much larger than 
lakes within the topographic depressions on the higher terraces. The altitude ranges from $2 \mathrm{~m}$ below sea level on the floodplains up to $53 \mathrm{~m}$. above sea level (a.s.l) on the high terraces.

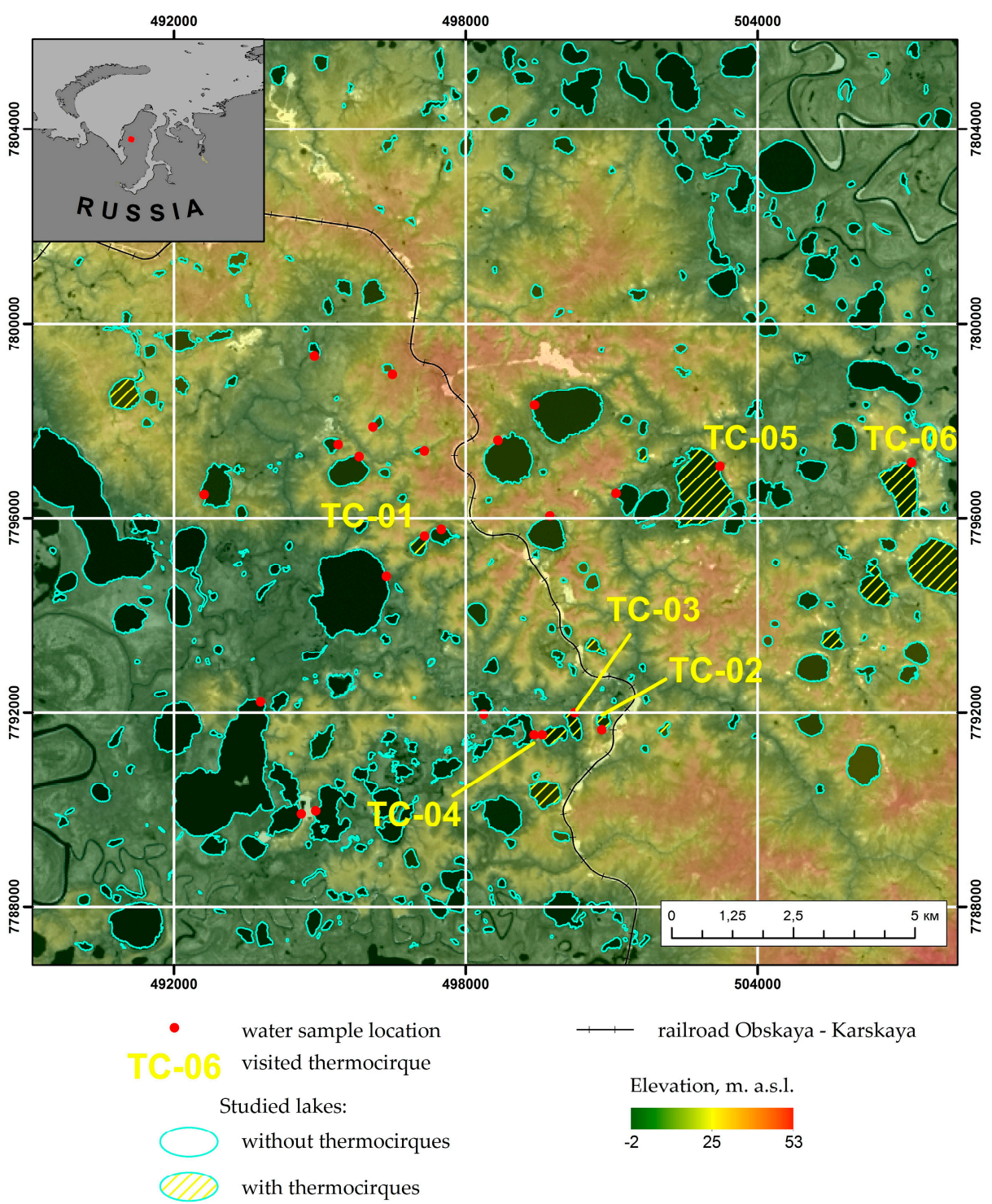

Figure 1. Map of the Vaskiny Dachi study region, showing the location of sampling (red points) during the 2014 field campaign. Thermocirques visited in the field are marked by yellow labels. Background: near-infrared band image of Landsat 8 satellite (19 July 2013) under half-transparent color-coded TanDEM-X digital elevation model (UTM Zone 42 North, WGS84).

The characteristics of lake shores within the study area vary from flat beaches to high cliffs. The presence of tabular ground ice in connection with active layer dynamics is responsible for massive cryogenic landsliding and thermodenudation in this area [22]. In 2012 and 2013 a noticeable activation of thermal denudation was observed in the area due to above average summer air temperatures [31]. The processes resulted in thermocirque development at several lake cliffs [32] which caused transport of large portions of thaw material into the lake waters [24].

Typical tundra of the bioclimatic subzone D covers the gently sloping upland surfaces and terraces $[33,34]$. Dense shrublands dominate on valley bottoms and gentle hill slopes representing old landslides [35]. Wetland vegetation and emerging macrophytes occupy the litoral zone of many lakes on the terraces. 


\section{Materials and Methods}

\subsection{Sample Collection and Measurements}

A total of 24 lakes within a $20 \mathrm{~km}$ distance from Vaskiny Dachi research station were selected for sampling in order to cover a wide range of CDOM values. The pre-selection was based on the inspection of satellite images in quasi-true color mode visualizing the apparent lake color and various lake types as well as catchments types. Lake color reflects the spectral properties of the water and thus is a proxy for CDOM concentration.

Water samples were collected in calm weather conditions with bottle sampling from the upper $30 \mathrm{~cm}$ of the water column close to the shore or in the center of lakes from a boat in August and September 2014 [24]. Samples from 24 lakes were collected (Figure 1, Table 1); 18 of them were located on high terraces and six were located on the floodplain of the Mordy-Yakha River.

Table 1. Central Yamal lakes from which the samples were taken for colored dissolved organic matter (CDOM).

\begin{tabular}{ccccc}
\hline Lake_ID & Longitude & Latitude & Position & Thermocirque \\
\hline LK-001 & 68.8828 & 70.2787 & High terrace & - \\
LK-002 & 68.9045 & 70.2976 & High terrace & - \\
LK-003 & 69.0019 & 70.2898 & High terrace & - \\
LK-004 & 68.9704 & 70.2809 & High terrace & - \\
LK-006 & 68.8991 & 70.2877 & High terrace & - \\
LK-007 & 68.9912 & 70.2672 & High terrace & - \\
LK-008 & 68.8113 & 70.2759 & High terrace & - \\
LK-010 & 68.8642 & 70.3012 & High terrace & - \\
LK-012 & 68.9218 & 70.2826 & High terrace & - \\
LK-013 & 68.8843 & 70.2563 & Floodplain & - \\
LK-014 & 68.8737 & 70.2835 & High terrace & - \\
LK-015 & 68.9217 & 70.2650 & High terrace & TC-01 \\
LK-016 & 68.9335 & 70.2668 & High terrace & - \\
LK-017 & 69.0221 & 70.2326 & High terrace & TC-02 \\
LK-018 & 69.0062 & 70.2319 & High terrace & TC-03 \\
LK-019 & 68.9951 & 70.2301 & High terrace & TC-04 \\
LK-020 & 68.9754 & 70.2311 & Floodplain & - \\
LK-022 & 68.9562 & 70.2358 & Floodplain & - \\
LK-024 & 68.8168 & 70.2215 & Floodplain & - \\
LK-025 & 69.0357 & 70.2738 & High terrace & - \\
LK-027 & 69.0757 & 70.2752 & High terrace & TC-05 \\
LK-031 & 69.1852 & 70.2756 & High terrace & TC-06 \\
LK-035 & 68.8737 & 70.2155 & Floodplain & - \\
LK-036 & 68.8491 & 70.2176 & Floodplain & - \\
\hline
\end{tabular}

The samples were filtered directly in the field after sampling. Filtrates for CDOM were prepared by filtering through Whatman(C) (Maidstone, UK) $0.7 \mu \mathrm{m}$ pore size glass fiber filters and were stored in cold and dark conditions to avoid photodegradation.

The filtrates were measured in the Otto Schmidt Laboratory (Saint-Petersburg, Russia) using a dual-beam spectrophotometer, Specord 200 (Jena Analytic@, Jena, Germany). CDOM absorption spectra were calculated from absorbance $(A)$ measurements in a range of $200-750 \mathrm{~nm}\left(\mathrm{a}(\lambda)_{\mathrm{CDOM}}\right)$ with $1 \mathrm{~nm}$ optical resolution. Logarithmic spectral slopes between 350 and $500 \mathrm{~nm}\left(\mathrm{~S}_{350-500}\left(\mathrm{~nm}^{-1}\right)\right)$ were calculated with $440 \mathrm{~nm}$ as reference wavelength $\mathrm{a}\left(\lambda_{0}\right)$. Parameter $\mathrm{a}(\lambda)_{\mathrm{CDOM}}$ decreases exponentially with the increasing of wavelength $\mathrm{a}\left(\lambda_{0}\right)$ and $S_{\lambda}$ (Equation (1), [36]):

$$
\mathrm{a}(\lambda)_{\mathrm{CDOM}}=\mathrm{a}\left(\lambda_{0}\right)_{\mathrm{CDOM}} \times \exp \left[-\mathrm{S}\left(\lambda_{0}-\lambda\right)\right.
$$


To calculate the absorption by CDOM per meter $\left(\mathrm{m}^{-1}\right)$, the measured absorbance (A) is transformed to a natural logarithm and corrected for the length of cuvette (Equation (2)):

$$
\mathrm{a}(\lambda)_{\mathrm{CDOM}}=2.303 \times \mathrm{A} / \mathrm{L}
$$

where $\mathrm{A}$ is absorbance (unitless) and $\mathrm{L}$ is the length of the cuvette in meters. In this study, Suprasil quartz cuvettes of 0.05 and $0.10 \mathrm{~m}$ length were used. Sample from the lake with thermocirque TC-06 (Figure 1) showed unrealistic high offset values of a $(700)_{C D O M}$. Offset-corrected values of a $(\lambda)_{C D O M}$ were obtained by subtracting the absorption value at $700 \mathrm{~nm}$ (where no CDOM absorption is assumed) because values not equal to 0 at this wavelength can occur due to scattering [27,30]. We restricted $\mathrm{a}(440)_{\mathrm{CDOM}}$ values from 2014 to a maximum value of $8 \mathrm{~m}^{-1}$, which has frequently been measured as maximum values in samples of other years.

\subsection{Remote Sensing And GIS Analyses to Derive Lake and Lake Catchment Characteristics}

We used a wide spectrum of geodata sources to derive lake and lake catchment characteristics including high-spatial resolution optical satellite data, synthetic aperture radar (SAR) satellite data and a SAR-derived digital elevation model (DEM).

\subsubsection{Geometrical and Radiometrical Pre-Processing of the Geodata}

The Central Yamal region was one of the first Arctic regions where TanDEM-X DEM data with $12 \mathrm{~m}$ resolution (Table 2) was made available (Deutsches Zentrum von Luft- und Raumfahrt, DLR). To improve the DEM for further processing, the raster data were converted to a point data model and re-interpolated using linear features such as digitized streams, water bodies, structure lines, and railway line. TopoToRaster was used as the interpolation method in ArcGIS 10.2.2. (ESRI Inc.C), Redlands, CA, USA).

Table 2. List of remote sensing data used. * Different types of data used (MS-multispectral, PS-pan-sharpened (PANSHARP2 model, [37]); ** orthorectification (OR) applied for all optical images using collected ground control points (GCPs) in the field with Differential Global Positioning System DGPS Trimble 5700 and corrected $12 \mathrm{~m}$ TanDEM-X digital elevation model (DEM); atmospheric correction (AC) applied for all MS images using ATCOR@ algorithm [38]. NDVI: normalized difference vegetation index; $\mathrm{CHL}$ : chlorophyll-related vegetation index.

\begin{tabular}{|c|c|c|c|c|c|c|}
\hline & $\begin{array}{l}\text { Sensor/ } \\
\text { [Bands] }\end{array}$ & Type * & Acquired & $\begin{array}{c}\text { Spatial } \\
\text { Resolution, } \\
\text { m }\end{array}$ & Correction Procedures ** & Products \\
\hline \multirow{4}{*}{$\begin{array}{l}\text { Optical } \\
\text { data }\end{array}$} & \multirow{2}{*}{$\begin{array}{l}\text { GeoEye-1/ } \\
{[4]}\end{array}$} & MS & \multirow[t]{2}{*}{5 July 2013} & 2 & $\begin{array}{l}\text { OR (GCPs, DEM), } \\
\text { ATCOR AC }\end{array}$ & CDOM retrieving \\
\hline & & PS & & 0.5 & OR (GCPs, DEM) & $\begin{array}{l}\text { thermocirque, streams, } \\
\text { lake in- and outlets digitizing }\end{array}$ \\
\hline & $\begin{array}{l}\text { WorldView-2/ } \\
{[8]}\end{array}$ & PS & 21 July 2013 & 0.5 & OR (GCPs, DEM) & $\begin{array}{l}\text { thermocirque, streams, } \\
\text { lake in- and outlets digitizing }\end{array}$ \\
\hline & $\begin{array}{l}\text { SPOT 5/ } \\
\text { [4] }\end{array}$ & MS & 8 August 2015 & 10 & OR, AC & NDVI and CHL vegetation indices \\
\hline $\begin{array}{c}\text { Radar } \\
\text { data }\end{array}$ & $\begin{array}{c}\text { TerraSAR-X/ } \\
{[1]}\end{array}$ & & 4 July 2014 & 3 & $\begin{array}{l}\text { OR, resampling, } \\
\text { radiometric normalization, } \\
\text { stacking }\end{array}$ & water body extraction \\
\hline DEM & $\begin{array}{l}\text { TanDEM-X } \\
\text { DEM }\end{array}$ & & July 2014 & 12 & $\begin{array}{l}\text { Leveling (water bodies), } \\
\text { streams, filling }\end{array}$ & $\begin{array}{l}\text { lake water level, catchment } \\
\text { delineation, topography, slope angle, } \\
\text { topographic wetness index (TWI), } \\
\text { snow water equivalent (SWE) }\end{array}$ \\
\hline
\end{tabular}


TerraSAR-X SAR satellite data (Table 2) were delivered in Level 1B SSC (single-look slant range Complex) processing with horizontal-horizontal $(\mathrm{HH})$ polarization. For data processing, the open source software NEST $\odot$ from the European Space Agency (ESA) was used. The data were terrain-corrected using range Doppler terrain correction and the TanDEM-X DEM product. The output pixel spacing was set to $2 \mathrm{~m}$ and projected into UTM Zone 42, WGS-1984. Radiometric normalization was applied and the resulting Sigma $\theta$ band was transferred to decibel $(\mathrm{dB})$ using the IDL@ 8.6 software.

ALOS PALSAR (Table 2) SAR satellite data were delivered in Level 1.1 processing with horizontal-vertical (HV) polarization for two dates (14 August 2008 and 19 September 2008). The multi-looking images were ellipsoid corrected using the geolocation-grid method in NESTC. The resulting intensity images were converted into $\mathrm{dB}$. The mean of the two dates was calculated and gamma-filtered.

Ground control points (GCP) at recognizable and fixed objects in satellite images were collected in August 2014 using Trimble@ 5700 differential global positioning system (DGPS) to geometrically correct the very high spatial resolution optical images (Table 2). Pan-sharpened images for optical satellite data from GeoEye-1 and WorldView-2 (Table 2) were obtained applying PANSHARP2 fusion algorithm developed by Zhang [37] for multispectral and panchromatic images using PCI Geomatica 2014 software (PCI Geomatics $\odot$ ). The orthorectification procedure was performed within OrthoEngine@ module in PCI Geomatica. The prepared DEM was used to correct the images for relief distortions towards orthoimage. ATCOR $\odot$ ground reflectance atmospheric correction module [38] was used to correct the multispectral image data of GeoEye-1 and WorldView-2 with PCI Geomatica software. We used "rural" as aerosol type and "subarctic summer" as atmospheric conditions suitable for tundra environment. The steep spectral attenuation derived from dark object substraction (DOS) for both GeoEye-1 and WorldView-2 images indicated high atmospheric transparency, and therefore we set the visibility to $80 \mathrm{~km}$ for the atmospheric correction. Ground reflectance data of different tundra surfaces were reliable compared with the bi-directional surface reflectance measured at the Greening of the Arctic Monitoring sites in the Vaskiny Dachi region in summer 2011 [39]. A seamless mosaic of two images was produced using ENVI@ 5.0 software.

Atmospherically corrected $10 \mathrm{~m}$ spatial resolution SPOT-5 (Take 5 product, ESA) were used to extract vegetation with large areal coverage.

\subsubsection{Remote Sensing Data Processing}

The seamless mosaic of multispectral atmospherically-corrected GeoEye-1 and WorldView-2 satellite data was used to retrieve CDOM concentration in 356 lakes in the area (Table 2). We used the green spectral band versus red spectral band ratio method $a(440)_{C D O M}=a(G / R)^{b}$ developed by Kutser et al. [40,41]. The band ratio values were calculated by dividing the reflectance values in the green band (green reflectance, G, $0-100 \%$ ) by the red band (red reflectance, R, $0-100 \%$ ). To extract the band ratio values the regions of interest (ROIs) were placed in the center of the lakes avoiding the shallow litoral areas. ROIs were $80-15,000 \mathrm{~m}^{2}$ depending on the lake size. We related ROI values to in-situ a(440) $\mathrm{CDOM}$ from summer 2014 (CDOM, Table 3). The overall time difference between satellite acquisitions and field sampling was approximately 11 months. Satellite-derived ratio values of cloud covered lakes were excluded from this empirical model (LK-001, LK-002, LK-006, LK-008, LK-010, LK-014). 
Table 3. List of lake and lake catchment characteristics used in CDOM statistical model. Variables in bold type were used in the final statistical processing.

\begin{tabular}{|c|c|c|c|c|c|}
\hline Code of Variable & Description of Variable & Dimension & Min & $\operatorname{Max}$ & Median \\
\hline CDOM & $\mathrm{a}(440)_{\mathrm{CDOM}}$ values, derived from optical satellite images (2013) & $\mathrm{m}^{-1}$ & 0.48 & 8.35 & 1.43 \\
\hline LK_PER & Lake perimeter & $\mathrm{km}$ & 0.14 & 11.89 & 0.7 \\
\hline LK_AR & Lake area & ha & 0.14 & 346.6 & 2.45 \\
\hline INLET & Inlet in form of river/stream & $0 / 1$ & \multicolumn{3}{|c|}{$0(n=289), 1(n=67)$} \\
\hline OUTLET & Outlet in form of river/stream & $0 / 1$ & \multicolumn{3}{|c|}{$0(n=239), 1(n=117)$} \\
\hline DR & Drainage ratio (CA_AR/LK_AR) & - & 0.59 & 181.3 & 5.93 \\
\hline POS & $\begin{array}{l}\text { Geomorphological setting of the lake ( } 0 \text {-floodplain of Se-Yakha and } \\
\text { Mordy-Yakha rivers, 1-III, IV, V geomorphological terraces) }\end{array}$ & $0 / 1$ & \multicolumn{3}{|c|}{$0(n=184), 1(n=172)$} \\
\hline LK_WL & Elevation of the lake water level & m a.s.l. & -1.7 & 39.3 & 6.27 \\
\hline TC & Thermocirque in the coastal rim & $0 / 1$ & \multicolumn{3}{|c|}{$0(n=341), 1(n=15)$} \\
\hline TWI & TWI index values & - & 2.43 & 9.55 & 6.12 \\
\hline CA_AR & Catchment area & ha & 0.25 & 713.9 & 20.49 \\
\hline CA_PER & Catchment perimeter & $\mathrm{km}$ & 0.31 & 32.77 & 2.77 \\
\hline SLOPE & Slope value & Degree & 0.79 & 8.41 & 2.74 \\
\hline SHR & Area covered by high shrubs & ha & 0 & 141.5 & 1.49 \\
\hline SHR_ & Percentage of the catchment area covered by high shrubs & $\%$ & 0 & 76.5 & 8.53 \\
\hline SWE & Potential water in the catchment in form of snow water equivalent (SWE) & $10^{5} \mathrm{~m}^{3}$ & 0.006 & 10.63 & 0.33 \\
\hline NDVI & Median of NDVI vegetation index in the catchment & - & 0.56 & 0.75 & 0.65 \\
\hline $\mathrm{CHL}$ & Median of $\mathrm{CHL}$ vegetation index in the catchment & - & 77 & 143 & 111 \\
\hline
\end{tabular}

Atmospherically corrected multispectral SPOT-5 data were used to calculate the normalized difference vegetation index (NDVI, Table 3) and a chlorophyll-related vegetation index (CHL, Table 3). Median NDVI and CHL per lake catchment were extracted for 356 catchments. Vegetation indices are based on the assumption that the main photosynthetically-active pigments of vegetation absorb in the red wavelength region $(650-700 \mathrm{~nm})$. The greener the vegetation, the higher the chlorophyll absorption and the lower the reflectance in the red band. More vegetation biomass results in multiple scattering in the near-infrared (NIR) and hence higher reflectance in the NIR. The commonly used NDVI index [42] is calculated using the following Equation (3):

$$
\mathrm{NDVI}=(\mathrm{NIR}-\mathrm{R}) /(\mathrm{NIR}+\mathrm{R})
$$

where NIR and $\mathrm{R}$ are the reflectance values in NIR and red bands, respectively.

Chlorophyll vegetation index (CHL) is calculated as relative absorption depth [38]:

$$
\mathrm{CHL}=(\mathrm{G}+\mathrm{NIR}) / 2-\mathrm{R}
$$

where $\mathrm{G}$ is the reflectance value in the green band.

The pan-sharpened optical satellite data were used to derive geomorphological features such as thermocirques (TC, Table 3) and lake in- and outlets (INLET and OUTLET, Table 3). The lake shores were inspected in order to find the active thermocirques (i.e., presence or absence). In additional, the area impacted by the thermocirques was calculated. All lakes were grouped according to their inlet-outlet regime within the stream network. This divided the lakes into four groups $[43,44]$ : (1) seepage (no apparent surface inlet or outlets); (2) seepage-inlet (inlets, no apparent surface outlets); (3) headwater (outlets, no apparent surface inlets); and (4) drainage lakes (inlets and outlets).

The TanDEM-X DEM was used to derive topography-related metrics (Table 2) including elevation of lake shorelines, lake catchments, topographic slope values, topographic wetness index (TWI), snow water equivalent (SWE). Lake catchments were calculated using the flow direction raster model in ArcHydro [45]. All automatically delineated catchment areas were manually corrected 
if there were surface outlets from the lake. Mean slopes values were calculated for each catchment averaging the values of each pixel within the catchment. The TWI index was calculated as described in Sørensen et al. [46]. SWE was calculated for all catchments using the snow survey data and Geographic Information System (GIS) based modelling [47]. A snow survey in the study area was carried out in March 2013. Snow depth was measured using a metal ruler and snow density with the snow sampler VS-43 designed for snow density measurements during snow surveys.

The TerraSAR-X satellite data (Table 2) was used to derive the areal extent of the lake water bodies (LK_AR, Table 3). Due to specular reflection on open water bodies, the resulting lower backscatter values from water can be used to differentiate between land and open water bodies [48]. Water body areas were extracted from the TerraSAR-X images acquired in summer 2014 using the backscatter threshold method. The ALOS PALSAR satellite data were used to create a shrub map for the study area and derive the percentage of shrub coverage within the catchments (SHR and SHR_PERC, Table 3). Processed ALOS PALSAR data were used to extract the areas of high shrubs by applying the backscatter threshold ( $\mathrm{dB}>-25)$, and then converting to vector data. The shrub percentage was calculated as the ratio of the area covered by high shrubs and the area of the catchment.

\subsection{Statistical Processing}

Regression tree model (RTM, rpart package [49]) and boosted regression tree (BRT, dismo package [50]) analyses were performed to investigate the relationship between satellite-derived $\mathrm{a}(440)_{\mathrm{CDOM}}$ values and 17 lake and lake catchment parameters (environmental variables) of 356 lakes (Table 3). RTM supports the analyses of the importance of multiple explanatory variables (lake and lake catchment characteristics) in respect to a specific response variable (CDOM concentration). RTM can also help to assess the way in which different variables behave in explaining the response variable, and thereby clarify environmental processes. The aim of BRT is a better regression analysis, especially to explore non-linear relationships between independent and dependent variables [50].

To reduce the number of independent variables in the final RTM and BRT setup, all the environmental variables were cross-correlated using corrplot package [51] in $R$ software ( $R$ version 3.3.1, [52]). Variables characterized by non-normal distribution were log10-transformed prior to analysis $[43,44]$. If several variables were significantly correlated to each other $(R>0.5)$, the variable with the highest correlation with CDOM was retained for further analysis.

\section{Results}

\subsection{CDOM of Central Yamal Lakes}

The biogeochemistry of the Central Yamal lakes is highly variable with a wide value range for CDOM, indicating high heterogeneity of lake type and influencing processes. In-situ measured $\mathrm{a}(440)_{\mathrm{CDOM}}$ values of 24 lakes from Central Yamal in 2014 ranged from 0.58 to $8 \mathrm{~m}^{-1}$ with a median value of $2.13 \mathrm{~m}^{-1}$ (Table 4). Values of $S_{350-500}$ ranged from 0.012 to 0.018 (median 0.0161, Table 3). Regression of in-situ a $(440)_{\mathrm{CDOM}}$ data and satellite $\mathrm{G} / \mathrm{R}$ ratio $(n=18)$ showed a significant $\left(R^{2}=0.79\right)$ correlation (Figure 2).

This relationship allowed us to calculate $\mathrm{a}(440)_{\mathrm{CDOM}}$ values for 356 lakes in the region ranging from 0.48 to $8.35 \mathrm{~m}^{-1}$ (median value $1.43 \mathrm{~m}^{-1}$ ). The final Equation (5) for calculating a $(440)_{\mathrm{CDOM}}$ from reflectance ratio is:

$$
\mathrm{a}(440)_{\mathrm{CDOM}}=8 \times(\mathrm{G} / \mathrm{R})^{-1.4}
$$




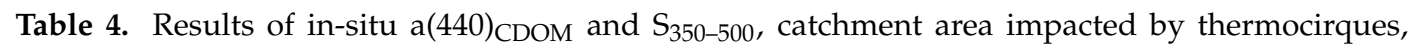
green $(\mathrm{G}) / \mathrm{red}(\mathrm{R})$ reflectance ratio of satellite images.

\begin{tabular}{|c|c|c|c|c|}
\hline Lake_ID & $\mathrm{a}(440)_{\mathrm{CDOM}}, \mathrm{m}^{-1}$ & $\mathrm{~S}_{350-500}, \mathrm{~nm}^{-1}$ & Impacted Area, ha & $G / R$ \\
\hline LK-001 & 0.82 & 0.0165 & - & Cloud covered \\
\hline LK-002 & 7.18 & 0.0165 & - & Cloud covered \\
\hline LK-003 & 0.89 & 0.018 & - & 4.1 \\
\hline LK-004 & 1.19 & 0.0165 & - & 1.9 \\
\hline LK-006 & 2.36 & 0.0182 & - & Cloud covered \\
\hline LK-007 & 1.35 & 0.0166 & - & 3.7 \\
\hline LK-008 & 3.82 & 0.0141 & - & Cloud covered \\
\hline LK-010 & 1.71 & 0.0172 & - & Cloud covered \\
\hline LK-012 & 2.30 & 0.018 & - & 1.9 \\
\hline LK-013 & 5.01 & 0.0153 & - & 2.5 \\
\hline LK-014 & 1.07 & 0.0160 & - & Cloud covered \\
\hline LK-015 & 6.34 & 0.0135 & 0.68 & 1.4 \\
\hline LK-016 & 4.18 & 0.0162 & - & 2.1 \\
\hline LK-017 & 4.64 & 0.0132 & 0.81 & 1.2 \\
\hline LK-018 & 5.46 & 0.0144 & 0.76 & 1.3 \\
\hline LK-019 & 7.65 & 0.0133 & 1.28 & 1.3 \\
\hline LK-020 & 1.72 & 0.0157 & - & 3.0 \\
\hline LK-022 & 1.96 & 0.0141 & - & 2.5 \\
\hline LK-024 & 0.85 & 0.0152 & - & 4.7 \\
\hline LK-025 & 0.74 & 0.0183 & - & 4.9 \\
\hline LK-027 & 2.39 & 0.0138 & 1.17 & 1.8 \\
\hline LK-031 & 8.00 & 0.0117 & 3.98 & 1.2 \\
\hline LK-035 & 1.52 & 0.0168 & - & 4.1 \\
\hline LK-036 & 0.58 & 0.0171 & - & 6.2 \\
\hline
\end{tabular}

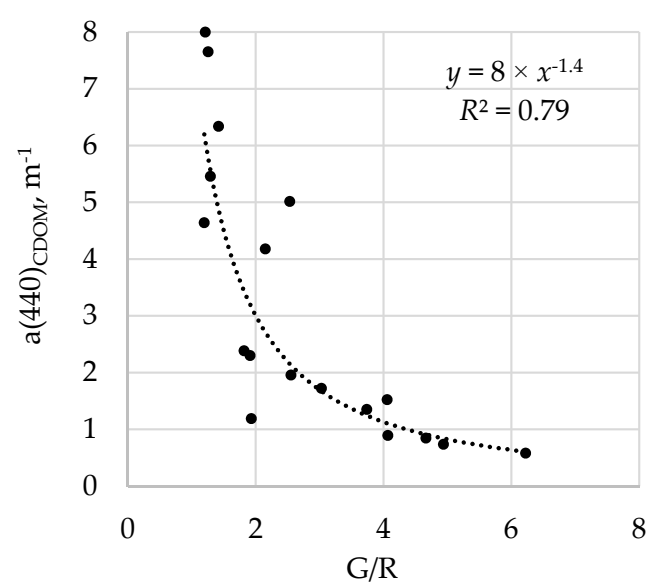

Figure 2. Comparison of measured CDOM absorption at $440 \mathrm{~nm}$ (2014) from the water samples versus the green reflectance/red reflectance $(G / R)$ ratio retrieved from mosaicked GeoEye-1 5 July 2013 and WorldView-2 21 July 2013 surface reflectance data set.

\subsection{Lake and Lake Catchment Parameters}

GIS and remote sensing data processing allowed us to extract 17 lake and lake catchment parameters from 356 lakes (Table 3). Remote sensing analyses showed that 15 lakes in the study area had shorelines with active thermocirques (4.2\%). 172 lakes were located on high terraces $(48.3 \%)$ with an average area of 8.47 ha. 184 lakes were located on floodplain of Se-Yakha and Mordy-Yakha Rivers (51.7\%) and are generally larger (average area $11.05 \mathrm{ha}$ ).

The median lake area equaled $2.45 \mathrm{ha}$, which indicated that lakes were generally small with several very large lakes (area $>100 \mathrm{ha}, n=7)$. Most of the lakes $(n=227,63.8 \%)$ were seepage lakes (without apparent inlets or outlets in form of river or stream), while $55(15.4 \%)$ were drainage lakes having an inlet and an outlet. Other lakes were seepage-inlet $(n=11)$ with an apparent inlet and no outlet, and headwater lakes $(n=62)$ with an apparent outlet and no inlet ( $3.1 \%$ and $24.2 \%$ respectively). 
Catchment area varied from 0.25 to 713.93 ha with the median value of 20.49 ha. Drainage ratio varied from 0.25 to 181.3 with the median value of 5.93. Five lakes were found with the water level below 0 a.s.l. with a minimum of $-1.7 \mathrm{~m}$ ). The highest lake level was $39.3 \mathrm{~m}$ with a median of $6.3 \mathrm{~m}$ a.s.l. Floodplain lakes had much lower levels compared to lakes on high terraces (with medians of 4.2 and $15.8 \mathrm{~m}$, respectively). The floodplain lakes had flatter catchments compared to lakes on high terraces with median slope values of $2.7^{\circ}$ and $3.2^{\circ}$, respectively). The area covered by high willow shrubs was as high as $76.5 \%$ of the catchment area with a median of $8.53 \%$. The median NDVI value for all catchments was relatively high for the area at 0.65 .

\subsection{Relationship Between CDOM and Environmental Variables in Yamal Lakes}

\subsubsection{Correlation Matrix}

The strongest positive relationship was found between CDOM and the presence of thermocirques on the lake shores $(R=0.49, n=356)$. The geomorphological position (floodplain or high terrace, $R=0.27, n=356)$ and mean slope value of the catchment $(R=0.22, n=356)$ showed weak positive relationships. Using the correlation matrix, interdependent variables can be detected and removed from the final dataset used for the RTM. Comparing the Pearson's correlation coefficients (Figure 3), 10 of 17 variables were chosen according to their association with CDOM and with each other (Table 4). They represent groups of variables: lake and lake catchment morphometry (lake perimeter, drainage ratio), hydrology (inlets and outlets), vegetation of the catchment (NDVI index, area covered by high shrubs), snow regime (SWE in the catchment), and geomorphology of the catchment (geomorphological position, slope). Although POS was highly correlated with CDOM compared to LK_WL $(R=0.22$ and $R=0.18$ ), we decided to use LK_WL in a final RTM and BRT analysis because this variable explains more difference among lakes.

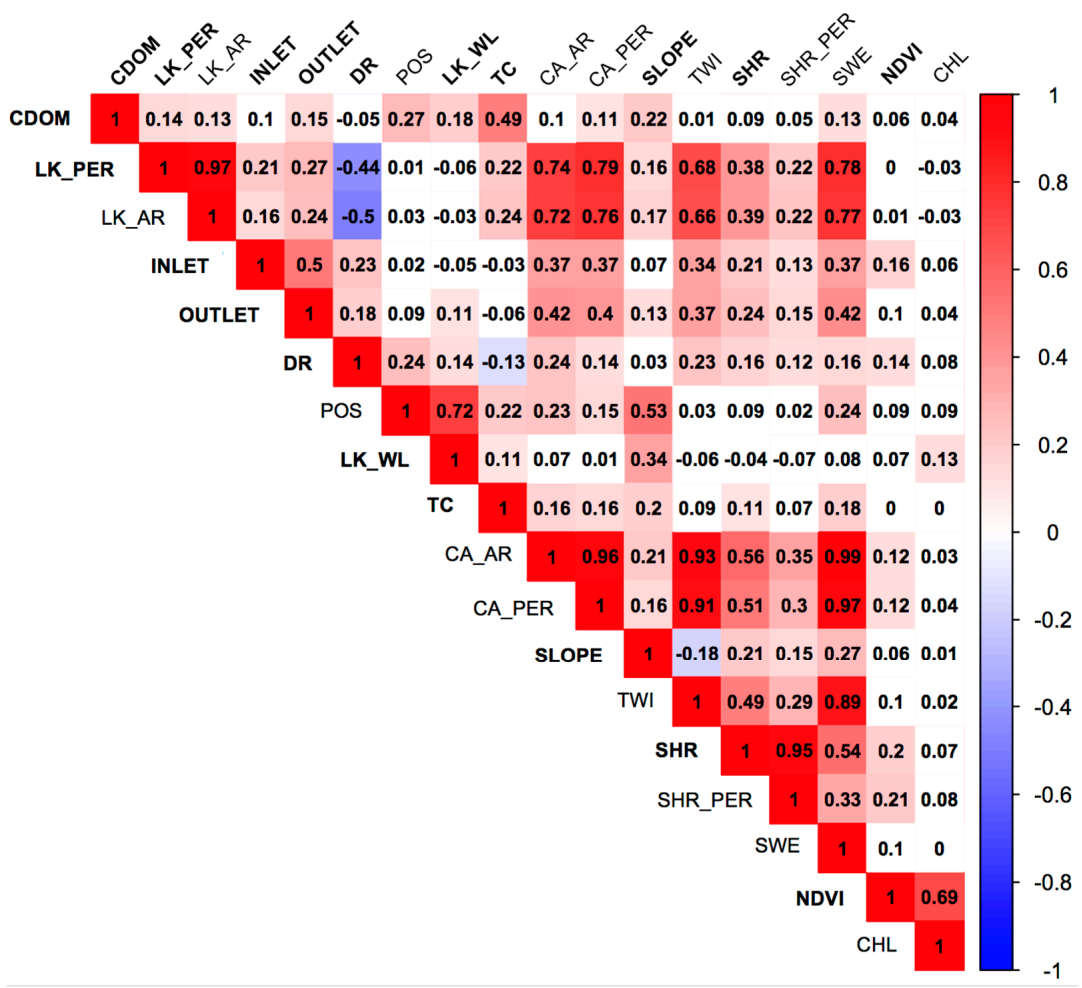

Figure 3. Correlation matrix of CDOM: lake and lake catchment dataset. Red color indicates positive relation of the parameters to CDOM, blue-inverse correlation. White color indicates correlations with $p>0.05$. See Table 3 for variable codes. Variables used in the final statistical processing are shown in bold. 


\subsubsection{Regression Tree Model (RTM)}

Ten environmental variables were used in the final RTM dataset (Figure 3). The RTM (Figure 4) shows the most important variables explaining CDOM concentration in Central Yamal lakes. The analysis divided the whole dataset into groups according to the importance of parameter values, with $R^{2}=0.61$.

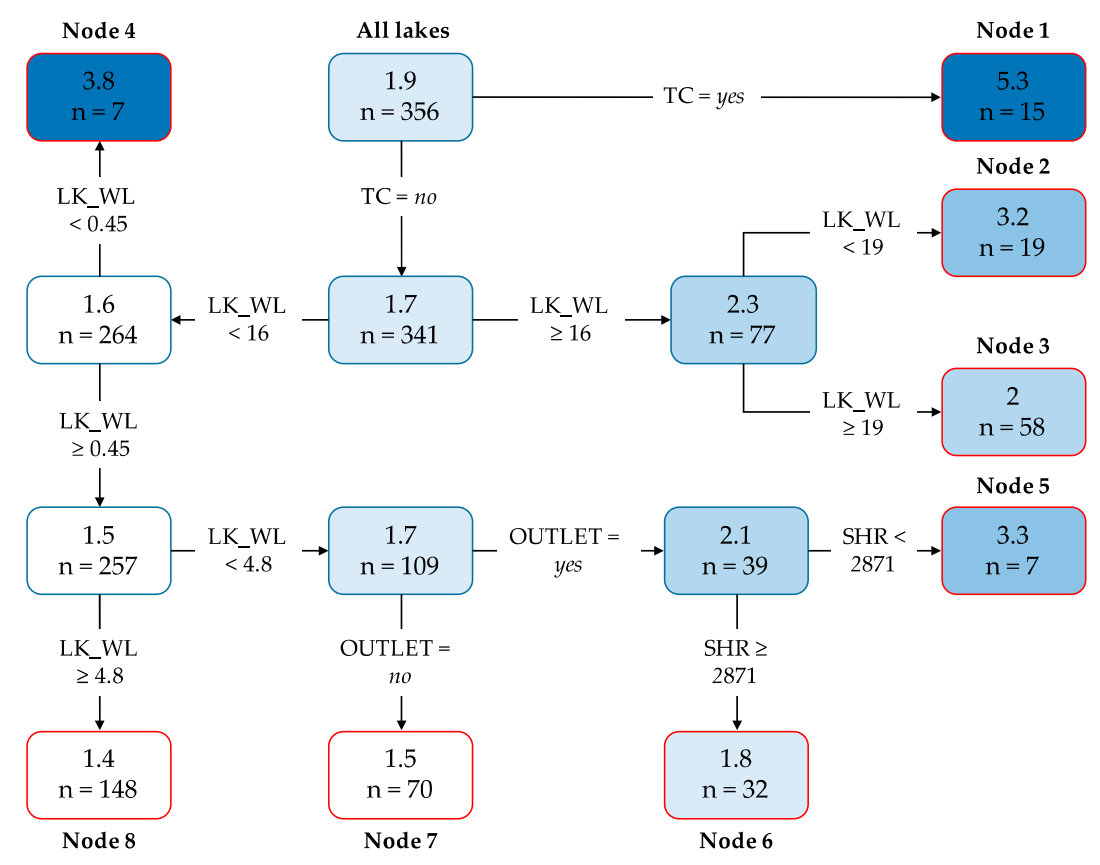

Figure 4. Regression tree explaining the environmental drivers of CDOM in Central Yamal lakes. The tree contains seven splits (boxes with a blue outline) and eight terminal nodes (boxes with red outline) and shows the mean values of a $(440)_{\mathrm{CDOM}}$ before splitting (upper value in the boxes), the lower value describes the number of cases in each node before splitting ( 356 cases $=100 \%$ ). Text between boxes reflects the environmental driver (Table 3) and a threshold value. Codes are given in Table 3. Bold text reflects the number of terminal node. Color of boxes represents the mean value of a $(440)_{\mathrm{CDOM}}$ within splits and terminal nodes.

The analysis yielded seven significant splits and eight terminal nodes (Figure 4). Presence/absence of thermocirques (TC) divides the whole dataset into two classes indicating a $(440)_{\mathrm{CDOM}}$ of 5.3 (Node 1) and $1.7 \mathrm{~m}^{-1}$ for lakes with- and without thermocirques respectively. The group of lakes without thermocirques $(n=341)$ on the lake shores is further divided according to lake water level (LK_WL) producing four terminal nodes (Figure 4): (1) $16 \mathrm{~m}<\mathrm{LK} \_\mathrm{WL}<19 \mathrm{~m}, n=19$ with mean value of a(440) $\mathrm{CDOM}=3.2 \mathrm{~m}^{-1}$ (Node 2); (2) LK_WL $\geq 19 \mathrm{~m}, n=58$ with mean value of $\mathrm{a}(440)_{\mathrm{CDOM}}=2.0 \mathrm{~m}^{-1}$ (Node 3); (3) LK_WL $<0.45 \mathrm{~m}, n=7$ with mean value of a(440) ${ }_{\mathrm{CDOM}}=3.8 \mathrm{~m}^{-1}$ (Node 4); (4) $4.8 \mathrm{~m}<\mathrm{LK} \_W L<16 \mathrm{~m}, n=148$ with mean value of a $(440)_{\mathrm{CDOM}}=1.4 \mathrm{~m}^{-1}$ (Node 8 ). The group of floodplain lakes with the second lowest lake water level between 0.45 and $4.8 \mathrm{~m}$ a.s.l. $(n=109)$ is further divided according to the presence of outlets (OUTLET) and area of catchment covered by high shrubs (SHR) producing 3 terminal nodes: (1) lakes without outlet, $n=70$ with mean value of a $(440)_{\mathrm{CDOM}}=1.5 \mathrm{~m}^{-1}$ (Node 7); (2) lakes with outlet and SHR $<2871 \mathrm{~m}^{2}, n=7$, with mean value of $\mathrm{a}(440)_{\mathrm{CDOM}}=3.3 \mathrm{~m}^{-1}$ (Node 5); (3) lakes with outlet and SHR $\geq 2871 \mathrm{~m}^{2}, n=32$, with mean value of $\mathrm{a}(440)_{\mathrm{CDOM}}=1.8 \mathrm{~m}^{-1}$ (Node 6$)$.

\subsubsection{Boosted Regression Tree (BRT) Analysis}

Ten environmental variables were used in the final BRT dataset (Figure 3). Two variablespresence/absence of thermocirques (TC), and the lake water level (LK_WL)—explained variations 
of lake CDOM (46.4\% and 28.4\%, respectively, Figure 5). BRT clearly defined two groups of lakes according to TC presence or absence, and several groups according to the LK_WL parameter. Two groups of LK_WL represented lakes with higher concentration of CDOM. These were the lakes on the lowest level in the floodplain with LK_WL $<1 \mathrm{~m}$ and lakes on the terraces between an altitudes of $16 \mathrm{~m} \leq$ LK_WL $<19 \mathrm{~m}$ (Figure 5) which also corresponded to the results obtained from RTM (terminal nodes 2 and 4, Figure 4). One group represented lakes with moderate CDOM concentration (LK_WL $>19 \mathrm{~m})$ and one group those with the lowest CDOM $\left(1 \mathrm{~m} \leq \mathrm{LK} \_W L<16 \mathrm{~m}\right)$.
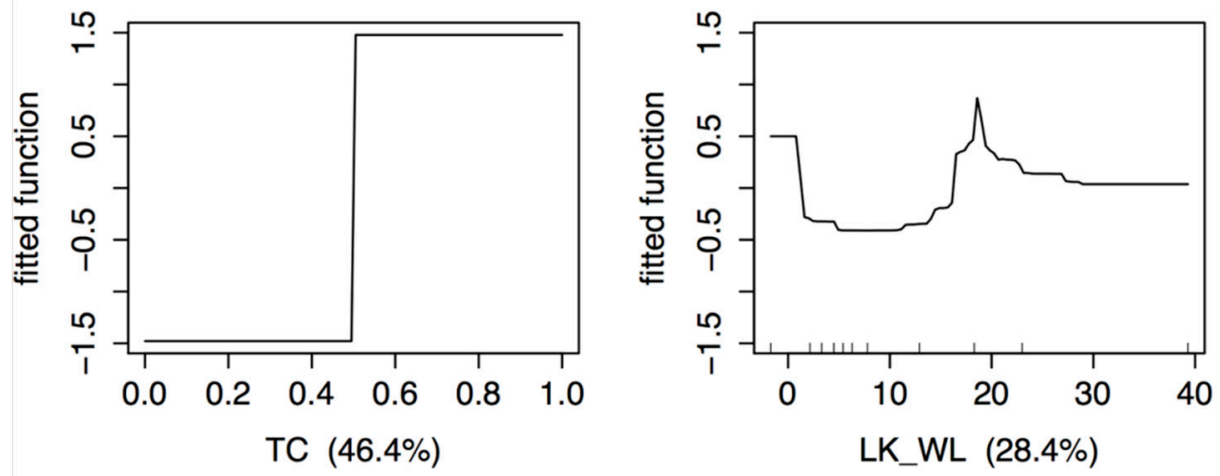

Figure 5. Results of boosted regression tree (BRT) analysis explaining the environmental drivers of CDOM in Central Yamal lakes. Number of plots decreased down to 2, showing the most important drivers. The percentage represents the degree of variable impact for the explanation of CDOM differences. The behavior of the line creates peaks and groups of lakes with higher and lower concentration of CDOM.

\section{Discussion}

\subsection{Organic Matter Content In Arctic Lakes}

Results of in-situ and remote sensing derived a $(440)_{\mathrm{CDOM}}$ values show moderate lake CDOM values in the Central Yamal Peninsula. A mean of 3.1, and median of $2.1 \mathrm{~m}^{-1}$ for a dataset of 24 lakes sampled in-situ (Table 3) and a mean of $1.9 \mathrm{~m}^{-1}$ and median of $1.4 \mathrm{~m}^{-1}$ for a dataset of satellite-derived CDOM from 356 lakes was observed. These results indicate that Central Yamal lakes are comparable with other Arctic lakes, including more southern lakes in terms of CDOM concentration (Table 5). To our knowledge, few studies on CDOM in lakes are available for Siberian tundra permafrost landscapes. Considering only in-situ data of the Central Yamal including different types of lakes, the mean regional value of $3.2 \mathrm{~m}^{-1}$ [24] is higher than the CDOM concentration sampled in lakes of other tundra landscapes such as the Lena River Delta [53], coastal areas of the Yamal and Gydan Peninsulas [54,55] and lower than CDOM measured in lakes around the Tazovskiy settlement on the Gydan peninsula $\left(6.1 \mathrm{~m}^{-1}\right.$, [56], Table 5).

Abnizova et al. and Manasypov et al. $[57,58]$ investigated DOC in lake-rich tundra landscapes in the Lena River Delta and Western Siberia. Both studies found lower DOC values than what we found for the lakes in the Central Yamal (unpublished data). It has also been shown that CDOM values in the lakes of the Lena River Delta are lower than those in Central Yamal lakes [53]. Lake catchments in Abnizova et al. and Manasypov et al. [57,58] are small and therefore relatively low influenced by snow melt in spring and are not characterized by large coverage of dense shrub biomass that is abundant in the Central Yamal. 
Table 5. CDOM absorption in Arctic lakes and water bodies found in the literature. In some cases the CDOM absorption results were given in other than $440 \mathrm{~nm}$ and we applied the equation 1 [36] to retrieve the absorption values for the needed wave length $440 \mathrm{~nm}$ : $\mathrm{a}(440)_{\mathrm{CDOM}}=\mathrm{a}(\lambda \mathrm{g})_{\mathrm{CDOM}} \times \exp [-\mathrm{S}(440-\lambda \mathrm{g})$, where $\mathrm{a}(\lambda \mathrm{g}) \mathrm{CDOM}$ is a CDOM absorption at given in the literature wavelength; $\mathrm{S}$ was considered equal to $0.015 \mathrm{~nm}^{-1}$ as often measured in both fresh waters and marine saline waters ([27] and references therein).

\begin{tabular}{|c|c|c|c|c|c|c|c|c|}
\hline \multirow{2}{*}{ Area } & \multirow{2}{*}{ Latitude } & \multirow{2}{*}{$\begin{array}{l}\text { Years of } \\
\text { Sampling }\end{array}$} & \multirow{2}{*}{ Water Bodies } & \multicolumn{4}{|c|}{$\mathrm{a}(440)_{\mathrm{CDOM}}, \mathrm{m}^{-1}$} & \multirow{2}{*}{ Reference } \\
\hline & & & & Range & Mean & St dev & $N$ & \\
\hline Canada (latitudinal gradient) & $46-80 \mathrm{~N}$ & 1999-2001 & Lake ice & $0.1-6.4$ & 3.2 & 2.2 & 13 & {$[60]$} \\
\hline Eastern Siberia, Kolyma basin & $68-70 \mathrm{~N}$ & $2008-2009$ & Kolyma river & $0.8-3.5$ & 1.8 & 0.9 & 18 & [61] \\
\hline Bolshezemelskaya tundra & $68 \mathrm{~N}$ & 2014 & Lakes & $0.98-9.78$ & 3.43 & 3 & 21 & [62] \\
\hline Gydan peninsula, Tazovskiy settlement & $67 \mathrm{~N}$ & 2016 & Lakes & $1.1-11.8$ & 6.1 & 3 & 14 & [56] \\
\hline Gydan peninsula, Gyda settlement & $70 \mathrm{~N}$ & 2016 & Lakes & $0.4-6.7$ & 3 & 2.4 & 5 & [56] \\
\hline $\begin{array}{l}\text { Coastal area of Yamal, Gydan and Yavay } \\
\text { peninsulas }\end{array}$ & $66-73 \mathrm{~N}$ & 2012-2014 & Lakes & $0.5-7.9$ & 2.5 & 2 & 44 & [54] \\
\hline Central Yamal & $70-71 \mathrm{~N}$ & 2014-2015 & Lakes & $0.58-8$ & 3.2 & 2.4 & 34 & [24] \\
\hline
\end{tabular}

Lakes in the boreal biome show higher CDOM than the Arctic biome. For example, Kutser et al. [40] measured 4-5 $\mathrm{m}^{-1}$ values in lakes of southern Sweden and Finland, and Breton et al. [59] measured values of 6-7 $\mathrm{m}^{-1}$ in Canadian thaw ponds in the boreal region, Belzile et al. (2002) [60] extracted $0.1-6.4 \mathrm{~m}^{-1}$ from lake ice along a latitudinal gradient in Canada.

Moderate CDOM concentrations in Central Yamal lakes are well in line with the overview work of Vincent et al. [15] describing that inland fresh water bodies north of tree line are characterized by low to moderate CDOM concentration which decreases as the distance from tree line increases [12]. Several studies $[5,63,64]$ which investigated water bodies in the taiga and close to the tree line and in discontinuous permafrost found mainly acidic and DOC-rich shallow thaw lakes.

\subsection{Impact of Landscape and Landscape Processes on CDOM of Yamal Lakes}

River catchments have been found to determine the organic matter concentration of surface waters [65]. In particular, the catchment properties and organic matter transport pathways have been of importance $[44,66]$. Correlations between lake DOC and GIS-extractable environmental variables were studied at a regional scale in different landscape types $[44,67]$ and it was found that lake and catchment areas are not the best predictors of lake DOC. Instead of lake and catchment morphometry, regional specific features such as portion of peatlands or wetlands in the catchment $[43,44]$ and soil carbon density or soil C:N ratio [67] were the most important predictors of lake DOC. However, small-scale regional models will likely not be applicable to explain lake DOC in other regions [44]. Soil organic matter concentration can be an important control of lake CDOM in Central Yamal, however it requires additional soil sampling and this variable has not been included in the analysis so far.

Our direct correlation analyses between CDOM and lake area and catchment area, has also shown a weak correlation $(R \leq 0.13)$. Our statistical analysis allowed the development a regional, Central Yamal theoretical model of organic matter transport (Figure 6) with landscape processes as determinants of lake CDOM. Thermocirques on lake shores led to increased organic matter input [24] and high CDOM in lakes (see Section 5.2.1). Lake water level also has an influence on CDOM (see Section 5.2.2). We assume that the process of the flooding of the lowest-lying lakes in spring due to snowmelt in the catchments and very high river water levels of streams and rivers in the floodplains are the other landscape processes impacting the tundra lakes of the Central Yamal. For the Mackenzie Delta in northwest, Canadian low-Arctic it was shown that variable flooding controlled lake limnology of floodplain lakes over an area of $10,000 \mathrm{~km}^{2}$ [68]. 


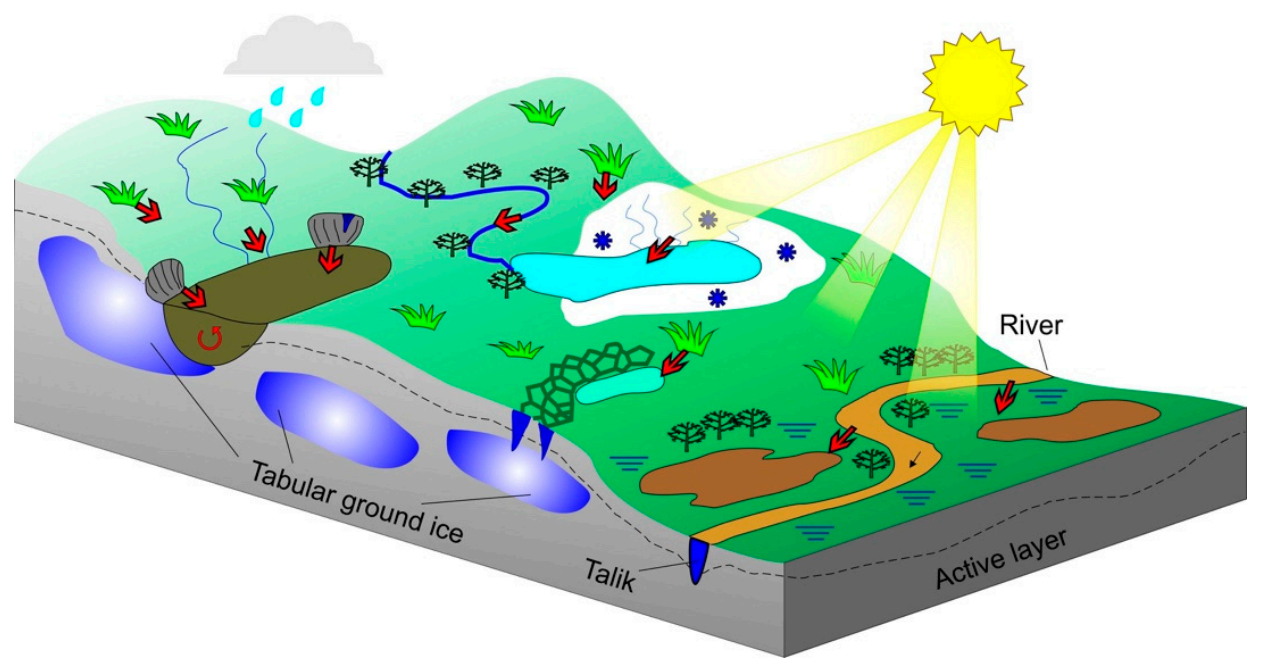

Figure 6. Theoretical scheme of the organic matter transport in Central Yamal lakes. Lakes are shown in different colors: thermocirque-impacted and floodplain lakes are more colored (brownish color) representing higher $\mathrm{CDOM}$ concentration. Red arrows represent the ways of organic matter transport to lakes from surrounding catchments.

\subsubsection{Impact of Thermocirques on Lake CDOM}

An extremely warm summer in 2012 activated thermocirques in the Central Yamal [31,32], which were responsible for large organic matter and sediment input into lakes [24,62]. Considering the larger area of analysis in this study, this small group of lakes with thermocirques $(n=15$, mean $\mathrm{a}(440)_{\mathrm{CDOM}}=5.3 \mathrm{~m}^{-1}$ ) was identified in the first split of the regression tree (node 1, Figure 4), indicating, that lakes with thermocirques form a separate group with high CDOM concentration. Recently we have shown that CDOM concentration in lakes can increase by $300-600 \%$ after the formation of thermocirques on its shores [24].

In contrast to our results for Central Yamal, Kokelj et al. [23,69] found a decrease in DOC in lakes in the Mackenzie Delta impacted by retrogressive thaw slumps (RTS). Kokelj et al. [24] and Thompson et al. [70] explain this decrease in lake DOC concentration by the removal of DOC due to coagulation and enhanced sedimentation processes with RTS-derived fine-grained clay particles.

Thermocirques of Central Yamal frequently expose peat layers, organic-rich sediments and slightly decomposed root layers that have accumulated on the paleorelief of the terraces of marine sediment sequences [24]. The thawing of exposed ground ice after thermocirque formation results in melt water transport with high organic matter input to the lakes (measured DOC concentration in pore water from peat layers was $243 \mathrm{mg} / \mathrm{L}$ [24]). Spectral slope (S) may provide information on the source of CDOM [27-29]. The steepness of the absorption spectra [27] is a proxy for CDOM composition, sources, and the ratio of humic and fulvic acids [28-30,71]. It has been shown, that the input of allochtonous CDOM is responsible for lower $S$ values [13], which is mainly attributed to a considerable proportion of humic acids having high molecular weight [72]. Our field data (Table 3) shows that thermocirque-impacted lakes are characterized by lower $S$ (mean value $0.0133 \mathrm{~nm}^{-1}$ ) compared to non-impacted ones (mean value $0.0165 \mathrm{~nm}^{-1}$ ). In this study, we did not investigate the organic matter quality in detail, but the presence of ancient organic matter in the geological sections of thermocirques in the form of peat can likely explain the differences between CDOM slope values in impacted and not impacted lakes [24].

\subsubsection{Impact of Lake Water Level on Lake CDOM}

The lakes located in the lowest positions on the floodplain area of the Mordy-Yakha River are characterized by high CDOM concentrations (mean a $(440)_{\mathrm{CDOM}}$ value $3.8 \mathrm{~m}^{-1}, n=7$, terminal node 4 , 
Figures 4 and 7) especially large lakes which are likely connected to the river and are inundated in the springtime. Our results also identify a small group of lakes $(n=19)$ that are characterized by higher concentrations of CDOM (mean a(440) $\mathrm{CDOM}$ value $3.2 \mathrm{~m}^{-1}$, node 2, Figures 4,5 and 7 ). Four of these lakes had a(440) $\mathrm{CDOM}$ values greater than $7 \mathrm{~m}^{-1}$ (LK-145, LK-189, LK-288, LK-262) as well as inlets (stream) connecting these lakes with the lake LK-387, the shore of which is impacted by a cryogenic landslide. In order to validate this system of connected lakes, we collected samples in lakes LK-387 and LK-262 in October 2016. The a(440) $\mathrm{CDOM}$ were found to be $4.0 \mathrm{~m}^{-1}$ and $5.0 \mathrm{~m}^{-1}$ respectively. It was less than values measured in 2013 ( 8.3 and $8.2 \mathrm{~m}^{-1}$ respectively) but still high compared to other lakes. Recently we have also shown, that after thermocirque activation the higher CDOM concentration in lakes starts to decrease [24]. The absolute height of the water for lakes of this group $(n=19)$ was between 16-19 $\mathrm{m}$ a.s.l. In our study area, this elevation corresponds with II-fluvial geomorphological terrace. We assume these lake catchment areas include portions of higher terraces (III-V), and that their topographic gradient is higher than for lakes located at higher elevations, despite the fact that the catchment slope parameter did not show high importance in the analysis. Catchment slope has been shown to be a relatively good predictor of DOC in lakes of Northern USA and Canada, but also sometimes inversely correlated with lake DOC [73]. Inverse correlation is explained by thinner soil organic horizons of steeper slopes and more exposed mineral B horizons which remove the DOC from water percolating through it [73] and by a higher degree of organic-rich waterlogged soil in catchments with flat topography [74]. In the area of continuous permafrost, fresh allochtonous organic material from vegetation will more likely reach the lake with steeper slopes as soon as the active layer is not deep. This likely explains the slight positive correlation of catchment slopes with lake CDOM (Figure 3). The topographic gradient implies snow melt water and rain water significantly erode the tundra of Yamal [75] and, consequently, flush organic material from the catchments into surface waters. The mean snow depth and snow density for the region are $30 \mathrm{~cm}$ and $0.33 \mathrm{~g} / \mathrm{cm}^{3}$ [47], respectively, which allows the catchments to accumulate up to 1 million $\mathrm{m}^{3}$ of water, depending on the catchment size and catchment morphology. Given the known depth of studied lakes and the possible volume of water, the snow storage in catchments in form of SWE can account for up to $13 \%$ of lake water volume in the summer period [56].

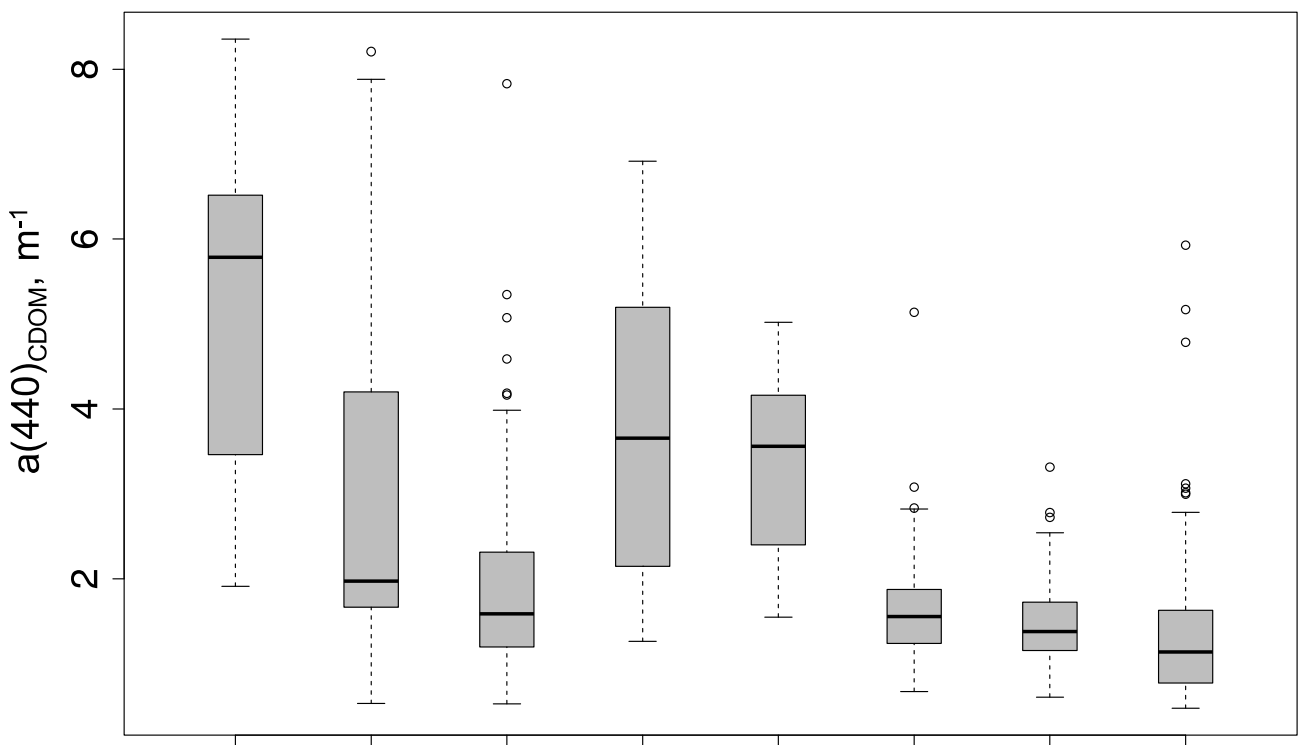

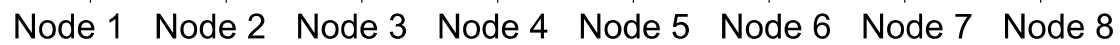

Figure 7. CDOM concentration of eight groups of lakes obtained from the regression tree model (RTM) (Figure 4). Numbers of the node can be taken from the Figure 4. 
The catchment vegetation and soils are a source of fresh terrestrial organic material. The Central Yamal tundra landscape differs from a zonal typical tundra landscape [76] in terms of having considerably higher vegetation biomass providing organic detritus along lake shores and within the lake catchments. The most productive vegetation in this particular area are high shrubs (Salix glauca, S. lanata), [35] on ancient cryogenic landslide surfaces [22] and stream valleys, grasses, on young and old cryogenic landslide surfaces [22], young drained lakes basins, and areas disturbed by off-road vehicle tracks [77]. Shrubs up to $2 \mathrm{~m}$ tall [34] may grow in depressions, concave slopes and valleys, protected from strong winds and filled by snow in wintertime [47]. The presence of this azonal vegetation is due to the high degree of mineralization of marine clayey soils [78] that is made available by active thermal denudation and cryogenic landslides [35]. However, this parameter did not show a significant influence on CDOM among lakes, but most likely the presence of shrubs in catchments controls the overall higher concentration of CDOM in lakes compared to other tundra landscapes of Siberia (Table 5).

\subsection{Potential of Remote Sensing and GIS for Mapping Lake CDOM, Lake Catchments and Parameterization of Lakes}

Optical remote sensing with very high, high and medium spatial resolution data permits the extraction of DOC concentration for inland waters [40]. In the Arctic, this is critical, since many lakes and ponds are relatively small in size but are very important for the carbon cycle [79,80]. However, a major challenge for deriving CDOM and DOC in lakes from optical remote sensing is the need for concomitant in-situ data and the requirement of high-quality satellite surface reflectance data for retrieval of CDOM $[40,41,81,82]$. The application of the green/red band ratio algorithm for derivation of lake CDOM $[40,41]$ uses an empirical relationship between water reflectance and in-situ CDOM related to the spectral properties of CDOM. Organic-rich surface water is characterized by higher absorption in shorter wavelengths (i.e., green reflectance band) than in the longer wavelengths such as the red reflectance band. From our experience, errors can occur applying this algorithm for acquisitions taken in times of high lake turbidity due to winds. The WorldView-2 and the GeoEye- 1 acquisitions used in this study were acquired during relatively calm wind conditions with no indication of enhanced lake turbidity due to sediment re-suspension. This is also supported by inspection of the panchromatic band of the images ( $0.5 \mathrm{~m}$ spatial resolution) where no waves can be recognized on the water bodies.

Within our field campaigns, we were able to sample a wide range of lake types from CDOM-rich to low CDOM. This wide range of CDOM concentrations supported the application of the green/red band ratio. The in-situ measured CDOM from 2014 and the band ratio from optical imagery in summer 2013 showed a significant correlation $\left(R^{2}=0.79, n=18\right)$. Before we fitted in-situ CDOM with satellite data, we investigated the variability of CDOM concentration between the years (data available from $2011[55,83]$ ) in order to avoid fitting lakes with strong CDOM dynamics. Though satellite acquisition closer to the date of sampling is preferred [40], other studies also correlated non-contemporaneous in-situ CDOM data with satellite acquisitions [84]. It was found that the temporal variability of CDOM in lakes in northern Canada appears to be relatively small, and large time lags (of several years) between ground data and satellite data produced slightly more scatter than the standard empirical CDOM models with timed field campaign [84]. The authors in Cardille et al. [84] found no indication of a bias toward an incorrect model when using CDOM field samples from a variety of years and that the important factor for CDOM algorithm creation is using a sufficiently large range of CDOM [84]. We show that using the absorption properties of CDOM we can map CDOM-regimes of the lakes in Central Yamal across a wide range of CDOM concentrations. Further studies with more field data from ongoing sampling for CDOM in Yamal lakes will provide further evaluation and accuracy experiments for satellite-derived CDOM. 


\section{Conclusions}

Our analysis shows that the landscape processes in lake catchments are important controls of CDOM in Central Yamal lakes. Specific landscape features of Central Yamal are (1) a wide distribution of tabular ground ice and the occurrence of thermocirques on the lake shores; (2) complex topography with highly dissected terrain; and (3) the presence of high shrubs in valleys and topographical depressions. All these specific features make the lakes of the region relatively rich in CDOM, compared to other Arctic regions.

We found that the occurrence of thermocirques on the lake shores is the most important control on lake CDOM in the region. Terrestrial organic matter input from thawed permafrost resulted in lakes with thermocirques being significantly different from lakes without. It remains unclear what the CDOM of these impacted lakes would become after stabilization of thermocirque development. Our analysis also shows that big floodplain lakes connected to the Mordy-Yakha River receive more organic matter, which should be studied further in detail. We did not find a significant correlation between catchment slope and lake CDOM. However, it is likely that lakes with catchment areas that incorporate all geomorphological levels can also receive more organic matter due to higher topographical gradients.

Remote sensing and GIS are important techniques for the retrieval of lake and lake catchment characteristics, and these geospatial data are important to investigate the statistical relationships within "lake-lake catchment" systems. In this study, we used high resolution GeoEye-1 and Worldview-2 multispectral satellite images in order to derive a(440) $\mathrm{CDOM}$ values. Further application of freely available Landsat- 8 and Sentinel-2 images with a sufficient radiometric and spatial resolution can be used for the assessment of terrestrial and freshwater ecosystem interactions in a larger spatial extent. This can also be a source of lake parameters in lake models.

Acknowledgments: This research was conducted within the framework of the Program of Fundamental Research Department of Earth Sciences No. 12 "The processes in the atmosphere and cryosphere as factors of environment changes", Presidential grant for scientific schools No. 5582.2012.5, 3929.2014.5, and 9880.2016.5 as well as international projects Circumpolar Active Layer Monitoring (CALM) and Thermal State of Permafrost (TSP). This work was supported by the Austrian Science Fund under Grant [I 1401] and Russian Foundation for Basic Research Grant 13-05-91001-ANF-a (Joint Russian-Austrian project COLD-Yamal). This work has been supported by Russian Science Foundation (RSF) grant No. 16-17-10203 through the database processing and analysis for thermokarst lakes to be compared to crater lakes. The Authors would like to thank for the personal advices: F. Günter concerning remote sensing data fusion and orthorectification; E. Dobrotina concerning the laboratory assistance; S. Zhuravlev concerning DEM processing for catchment delineation; M. Greenacre for valuable comments and advice on statistical processing of the data; A. Beamish for valuable editing and improvements to the manuscript; German Academic Exchange Service (DAAD), Otto Schmidt Laboratory for Polar and Marine Research (OSL) and Helmholtz graduate school for Polar and Marine Research (POLMAR) and the Helmholtz program for Regional Climate Change REKLIM for financial support; Digital Globe Foundation, German Aerospace Center (DLR, TDX-PI HYDR0226 and TSX-PI LAN1706), Japanese Space Agency (JAXA, ALOS2-PI1200) and ESA \& CNES for providing satellite images. We thank 3 anonymous reviewers and the editor for valuable comments and improvements to the manuscript.

Author Contributions: Y.D. and B.H. designed the study and performed optical satellite data processing and data retrieval as well as the GIS analysis; Y.D., and A.K. collected the field data; Y.D. and T.S. performed the laboratory measurements; Y.D. and U.H. performed statistical processing and data analysis; A.B. and B.W. provided digital elevation model and performed a processing of radar satellite images as well as a retrieval of environmental variables; I.F. and S.R. operationally managed the laboratory measurements at the Otto Schmidt Laboratory, OSL; A.G. consulted the selection of field sites; S.R. developed automatic CDOM data processing and consulted the data analysis; M.L. was a supervisor of the study and field work and contributed significantly to the manuscript preparation and editing; Y.D., B.H. and U.H wrote the paper.

Conflicts of Interest: The authors declare no conflicts of interest. 


\section{References}

1. Lehner, B.; Döll, P. Development and validation of a global database of lakes, reservoirs and wetlands. J. Hydrol. 2004, 296, 1-22. [CrossRef]

2. Smith, L.C.; Sheng, Y.; MacDonald, G.M. A first pan-arctic assessment of the influence of glaciation, permafrost, topography and peatlands on Northern Hemisphere lake distribution. Permafr. Periglac. Process. 2007, 18, 201-208. [CrossRef]

3. Grosse, G.; Jones, B.; Arp, C. Thermokarst lakes, drainage, and drained basins. In Treatise on Geomorphology; Shroder, J., Giardino, R., Harbor, J., Eds.; Academic Press: San-Diego, CA, USA, 2013; pp. 325-353.

4. Romanovskii, N.N. Basics of Lithosphere Cryogenesis; Moscow State University Press: Moscow, Russia, 1993; p. 336. (In Russian)

5. Vonk, J.E.; Mann, P.J.; Davydov, S.; Davydova, A.; Robert, G.M.S.; Schade, J.; Sobczak, W.V.; Zimov, N.; Zimov, S.; Bulygina, E.; et al. High biolability of ancient permafrost carbon upon thaw. Geophys. Res. Lett. 2013, 40, 2689-2693. [CrossRef]

6. Granéli, W.; Lindell, M.; Tranvik, L. Photo-oxidative production of dissolved inorganic carbon in lakes of different humic content. Limnol. Oceanogr. 1996, 41, 698-706. [CrossRef]

7. Tranvik, L.; Downing, J.A.; Cotner, J.B.; Loiselle, S.A.; Striegl, R.G.; Ballatore, T.J.; Dillon, P.; Finlay, K.; Fortino, K.; Knoll, L.B. Lakes and reservoirs as regulators of carbon cycling and climate. Limnol. Oceanogr. 2009, 54, 2298-2314. [CrossRef]

8. Gonsior, M.; Schmitt-Kopplin, P.; Bastviken, D. Depth-dependent molecular composition and photo-reactivity of dissolved organic matter in a boreal lake under winter and summer conditions. Biogeosciences 2013, 10, 6945-6956. [CrossRef]

9. Wetzel, R.G. Limnology: Lake and River Ecosystems; Academic Press: San-Diego, CA, USA, 2001; pp. 731-759.

10. Engström, D.R. Influence of vegetation and hydrology on the humus budgets of Labrador lakes. Can. J. Fish. Aquat. Sci. 1987, 44, 1306-1314. [CrossRef]

11. Zaneveld, J.R.V. Penetration of ultraviolet radiation into natural waters. Impacts Clim. Change Biosph. CIAP Monogr. 1975, 5, 108-166.

12. Vincent, W.F.; Pienitz, R. Sensitivity of high latitude freshwater ecosystems to global change: Temperature and solar ultraviolet radiation. Geosci. Can. 1996, 23, 231-236.

13. Laurion, I.; Vincent, W.F.; Lean, D.R.S. Underwater ultraviolet radiation: Development of spectral models for northern high latitude lakes. Photochem. Photobiol. 1997, 65, 107-114.

14. Twardowski, M.S.; Donaghay, P.L. Separating in-situ and terrigenous sources of absorption by dissolved material in coastal waters. J. Geophys. Res. 2001, 106, 2545-2560. [CrossRef]

15. Vincent, W.F.; Laurion, I.; Pienitz, R. Arctic and Antarctic lakes as optical indicators of global change. Ann. Glaciol. 1998, 27, 691-696. [CrossRef]

16. Pienitz, R.; Smol, J. Diatom assemblages and their relationship to environmental variables in lakes from the boreal forest-tundra ecotone near Yellowknife, Northwest Territories, Canada. Hydrobiologia 1993, 269-270, 391-404. [CrossRef]

17. Pienitz, R.; Smol, J.P.; Lean, D.R.S. Physical and chemical limnology of 59 lakes located between the southern Yukon and the Tuktoyaktuk Peninsula, Northwest Territories (Canada). Can. J. Fish. Aquat. Sci. 1997, 54, 347-358. [CrossRef]

18. Vonk, J.E.; Tank, S.E.; Bowden, W.B.; Laurion, I.; Vincent, W.F.; Alekseychik, P.; Amyot, M.; Billet, M.F.; Canário, J.; Cory, R.M.; et al. Reviews and syntheses: Effects of permafrost thaw on Arctic aquatic ecosystems. Biogeosciences 2015, 12, 7129-7167. [CrossRef]

19. Romanovsky, V.; Smith, S.; Christiansen, H. Permafrost thermal state in the polar Northern Hemisphere during the International Polar Year 2007-2009: A synthesis. Permafr. Periglac. Process. 2010, 21, 106-116. [CrossRef]

20. Zhang, T.; Osterkamp, T.E.; Stamnes, K. Effects of climate on the active layer and permafrost on the North Slope of Alaska, U.S.A. Permafr. Periglac. Process. 1997, 8, 45-67. [CrossRef]

21. Mackay, J.R. The Mackenzie Delta region, Northwest Territories. In Geographical Branch, Mines and Technical Surveys; Queen's Printer: Ottawa, ON, Canada, 1963; pp. 1-202.

22. Leibman, M.O.; Kizyakov, A.I. Cryogenic Landslides of the Yamal and Yugorsky Peninsulas; Earth Cryosphere Institute SB RAS: Moscow, Russia, 2007; pp. 1-206. (In Russian) 
23. Kokelj, S.V.; Jenkins, R.E.L.; Milburn, D.; Burn, C.R.; Snow, N. The influence of thawing permafrost on the water quality of small lakes across the forest 137 tundra transition, Mackenzie Delta region, Northwest Territories, Canada. Permafr. Periglac. Process. 2005, 16, 343-353. [CrossRef]

24. Dvornikov, Y.A.; Leibman, M.O.; Heim, B.; Khomutov, A.V.; Roessler, S.; Gubarkov, A.A. Thermodenudation on Yamal peninsula as a source of the dissolved organic matter increase in thaw lakes. Kriosf. Zemli 2017, 21, 33-42. [CrossRef]

25. Gjessing, E.T. Physical and Chemical Characteristics of Aquatic Humus; Ann Arbor Science Publishers: Ann Arbor, MI, USA, 1976; pp. 1-120.

26. Thurman, E.M. Determination of aquatic humic substances in natural waters. Sel. Pap. Hydrol. Sci. 1983, W2262, 47-52.

27. Twardowski, M.S.; Boss, E.; Sullivan, J.M.; Donaghay, P.L. Modeling spectral absorption by chromophoric dissolved organic matter (CDOM). Mar. Chem. 2004, 89, 69-88. [CrossRef]

28. Helms, J.R.; Stubbins, A.; Ritchie, J.D.; Minor, E.C.; Kieber, D.J.; Mopper, K. Absorption spectral slopes and slope ratios as indicators of molecular weight, source, and photobleaching of chromophoric dissolved organic matter. Limnol. Oceanogr. 2008, 53, 955-969. [CrossRef]

29. Carder, K.L.; Steward, R.G.; Harvey, G.R.; Ortner, P.B. Marine humic and fulvic acids: Their effects on remote sensing of ocean chlorophyll. Limnol. Oceanogr. 1989, 34, 68-81. [CrossRef]

30. Davies-Colley, R.J.; Vant, W.N. Absorption of light by yellow substance in freshwater lakes. Limnol. Oceanogr. 1987, 32, 416-425. [CrossRef]

31. Leibman, M.O.; Khomutov, A.V.; Gubarkov, A.A.; Mullanurov, D.R.; Dvornikov, Y.A. The research station "Vaskiny Dachi", Central Yamal, West Siberia, Russia-A review of 25 years of permafrost studies. Fennia 2015, 193, 3-30.

32. Khomutov, A.V.; Leibman, M.O.; Dvornikov, Y.A.; Gubarkov, A.A.; Mullanurov, D.R.; Khairullin, R. Activation of Cryogenic Earth Flows and Formation of Thermocirques on Central Yamal as a Result of Climate Fluctuations. In Proceedings of the World Landslide Forum 2017, Advancing Culture of Living with Landslides, Lyubljana, Slovenia, 29 May-2 June 2017; Mikoš, M., Vilímek, V., Yin, Y., Sassa, K., Eds.; Springer: Cham, Germany, 2017; pp. 209-216.

33. CAVM Team. Circumpolar Arctic Vegetation Map Conservation of Arctic Flora and Fauna Map (CAFF) Map No. 1; U.S. Fish and Wildlife Service: Anchorage, AK, USA, 2003.

34. Rebristaya, O.V.; Khitun, O.V. Botanical-geographic specifics of the Central Yamal's flora. Bot. Z. 1998, 83, 37-52. (In Russian)

35. Ukraintseva, N.G.; Leibman, M.O.; Streletskaya, I.D.; Mikhaylova, T. Geochemistry of plant-soil-permafrost system on landslide-affected slopes, Yamal, Russia as an indicator of landslide age. In Landslides in Cold Regions in the Context of Climate Change, Environmental Science and Engineering; Shan, W., Guo, Y., Wang, F., Marui, H., Strom, A., Eds.; Springer International Publishing: Cham, Switzerland, 2014; pp. 107-132. [CrossRef]

36. Bricaud, A.; Morel, A.; Prieur, L. Absorption by dissolved organic matter of the sea (yellow substance) in the UV and visible domains. Limnol. Oceanogr. 1981, 26, 43-53. [CrossRef]

37. Zhang, Y. Highlight Article: Understanding Image Fusion. Photogramm. Eng. Remote Sens. 2004, 70, 657-661.

38. Richter, R. A spatially adaptive fast atmospheric correction algorithm. Int. J. Remote Sens. 1994, 17, $1201-1214$. [CrossRef]

39. Buchhorn, M.; Walker, D.A.; Heim, B.; Reynolds, M.; Epstein, H.; Schwieder, M. Ground-based hyperspectral characterization of Alaska tundra vegetation along environmental gradients. Remote Sens. 2013, 5, 3971-4005. [CrossRef]

40. Kutser, T.; Pierson, D.C.; Kallio, K.; Reinart, A.; Sobek, S. Mapping lake CDOM by satellite remote sensing. Remote Sens. Environ. 2005, 94, 535-540. [CrossRef]

41. Kutser, T.; Pierson, D.C.; Tanvik, L.; Reinart, A.; Sobek, S.; Kallio, K. Using satellite remote sensing to estimate the colored dissolved organic matter absorption coefficient in lakes. Ecosystems 2005, 8, 709-720. [CrossRef]

42. Tucker, C.J. Red and near-infrared linear combinations for monitoring vegetation. Remote Sens. Environ. 1979, 8, 127-150. [CrossRef]

43. Kortelainen, P. Content of total organic carbon in Finnish lakes and its relationship to catchment characteristics. Can. J. Fish. Aquat. Sci. 1993, 50, 1477-1483. [CrossRef] 
44. Xenopoulos, M.A.; Lodge, D.M.; Frentress, J.; Kreps, T.A.; Bridgham, S.D.; Grossman, E.; Jackson, C.J. Regional comparisons of watershed determinants of dissolved organic carbon in temperate lakes from the Upper Great Lakes region and selected regions globally. Limnol. Oceanogr. 2003, 48, 2321-2334. [CrossRef]

45. Djokic, D.; Ye, Z.; Dartiguenave, C. Archydro Tools Overview; ESRI: Redland, CA, USA, 2011; pp. 1-189.

46. Sørensen, R.; Zinko, U.; Seibert, J. On the calculation of the topographic wetness index: Evaluation of different methods based on field observations. Hydrol. Earth Syst. Sci. 2006, 10, 101-112. [CrossRef]

47. Dvornikov, Y.A.; Khomutov, A.V.; Mullanurov, D.R.; Ermokhina, K.A.; Gubarkov, A.A.; Leibman, M.O. GIS and field data-based modelling of snow water equivalent in shrub tundra. Fennia 2015, 193, 53-65.

48. Bartsch, A.; Wagner, W.; Scipal, K.; Pathe, C.; Sabel, D.; Wolski, P. Global monitoring of wetlands-The value of ENVISAT ASAR Global mode. J. Environ. Manag. 2009, 90, 2226-2233. [CrossRef] [PubMed]

49. Therneau, T.M.; Atkinson, B. Package Rpart. 2018. Available online: http://cran.r-project.org/web/ packages/rpart/index.html (accessed on 2 November 2017).

50. Elith, J.; Leathwick, J.R.; Hastie, T. A working guide to boosted regression trees. J. Anim. Ecol. 2008, 77, 802-813. [CrossRef] [PubMed]

51. Wei, T. Package 'Corrplot'. 2017. Available online: https://cran.r-project.org/web/packages/corrplot/ corrplot.pdf (accessed on 6 January 2018).

52. R Core Team. R: A Language and Environment for Statistical Computing; R Foundation for Statistical Computing: Vienna, Austria, 2014.

53. Skorospekhova, T.; Heim, B.; Fedorova, I.; Morgenstern, A.; Eulenburg, A.; Alekseeva, N.; Evdokimov, A.; Chetverova, A.; Romanov, S. Colored dissolved organic matter (CDOM) absorption measurements of lakes in the Lena River Delta, Eastern Siberia, 2013-2016. PANGAEA 2017. [CrossRef]

54. Skorospekhova, T.; Fedorova, I.; Evdokimov, A.; Shadrina, A.; Alekseeva, N.; Chetverova, A.; Heim, B. Colored dissolved organic matter (cDOM) absorption measurements in terrestrial water objects of Yamal, Yavai and Gydan Peninsula. PANGAEA 2016. [CrossRef]

55. Dvornikov, Y.; Heim, B.; Roessler, S.; Leibman, M.; Khomutov, A.; Bartsch, A. Colored dissolved organic matter (CDOM) absorption measurements in the Vaskiny Dachi region, Central Yamal, Russia. PANGAEA 2016. [CrossRef]

56. Dvornikov, Y. Earth Cryosphere Institute SB RAS, Tyumen, Russia. Unpublished work. 2016.

57. Abnizova, A.; Siemens, J.; Langer, M.; Boike, J. Small ponds with major impact: The relevance of ponds and lakes in permafrost landscapes to carbon dioxide emissions. Glob. Biogeochem. Cycles 2012, 26, GB2041. [CrossRef]

58. Manasypov, R.M.; Vorobyev, S.N.; Loiko, S.V.; Krivtzov, I.V.; Shirokova, L.S.; Shevchenko, V.P.; Kirpotin, S.N.; Kulizhsky, S.P.; Kolesnichenko, L.G.; Zemtsov, V.A.; et al. Seasonal dynamics of thermokarst lake chemical composition in discontinuous permafrost zone of Western Siberia. Biogeosciences 2015, 12, 3009-3028. [CrossRef]

59. Breton, J.; Valliere, C.; Laurion, I. Limnological properties of permafrost thaw ponds in northeastern Canada. Can J. Fish Aquat. Sci. 2009, 66, 1635-1648. [CrossRef]

60. Belzile, C.; Gibson, J.A.E.; Vincent, W.F. Colored dissolved organic matter and dissolved organic carbon exclusion from lake ice: Implications for irradiance transmission and carbon cycling. Limnol. Oceanogr. 2002, 5, 1283-1293. [CrossRef]

61. Griffin, C.G.; Frey, K.E.; Rogan, J.; Holmes, R.M. Spatial and interannual variability of dissolved organic matter in the Kolyma River, East Siberia, observed using satellite imagery. J. Geophys. Res. 2011, 116, G03018. [CrossRef]

62. Dvornikov, Y. The Processes of Thermodenudation in Cryolithozone and the Dissolved Organic Matter as their Indication. Ph.D. Thesis, Earth Cryosphere Institute SB RAS, Tyumen, Russia, 2016; pp. 1-177. (In Russian)

63. Audry, S.; Pokrovsky, O.S.; Shirokova, L.S.; Kirpotin, S.N.; Dupré, B. Organic matter mineralization and trace element post-depositional redistribution in Western Siberia thermokarst lake sediments. Biogeosciences 2011, 8, 3341-3358. [CrossRef]

64. Laurion, I.; Vincent, W.F.; MacIntyre, S.; Retamal, L.; Dupont, C.; Francus, P.; Pienitz, R. Variability in greenhouse gas emissions from permafrost thaw ponds. Limnol. Oceanogr. 2010, 55, 115-133. [CrossRef]

65. Larson, J.H.; Forst, P.C.; Zheng, Z.; Johnston, C.A.; Bridgham, S.D.; Lodge, D.M.; Lamberti, G.A. Effects of upstream lakes on dissolved organic matter in streams. Limnol. Oceanogr. 2007, 52, 60-69. [CrossRef]

66. Mulholland, P.J. Large-scale patterns in dissolved organic carbon concentration, flux, and sources. In Aquatic Ecosystems - Interactivity of Dissolved Organic Matter; Findlay, S., Sinsabaugh, R.L., Eds.; Academic Press: Cambridge, MA, USA, 2003; pp. 139-160. 
67. Sobek, S.; Tranvik, L.J.; Prairie, Y.T.; Kortelainen, P.; Cole, J.J. Patterns and regulation of dissolved organic carbon: An analysis of 7,500 widely distributed lakes. Limnol. Oceanogr. 2007, 52, 1208-1219. [CrossRef]

68. Lesack, L.F.W.; Marsh, P.; Hecky, R.E. Spatial and temporal dynamics of major solute chemistry among Mackenzie Delta lakes. Limnol. Oceanogr. 1998, 7, 1530-1543. [CrossRef]

69. Kokelj, S.V.; Zajdlik, B.; Thompson, M.S. The impacts of thawing permafrost on the chemistry of lakes across the subarctic boreal-tundra transition, Mackenzie Delta region, Canada. Permafr. Periglac. Process. 2009, 20, 185-199. [CrossRef]

70. Thompson, M.S.; Kokelj, S.V.; Wrona, F.J.; Prowse, T.D. The impact of sediments derived from thawing permafrost on tundra lake water chemistry: An experimental approach. In Proceedings of the IX International Conference on Permafrost, Fairbanks, Alaska, USA, 28 June-3 July 2008; Book of Abstracts. Kane, D.L., Hinkel, K.M., Eds.; Institute of Northern Engineering, University of Alaska Fairbanks: Fairbanks, AK, USA, 2008; Volume 2, pp. 1763-1768.

71. Blough, N.V.; Green, S.A. Spectroscopic characterization and remote sensing of non-living organic matter. Proceedings of Dahlem Workshop on the Role of Nonliving Organic Matter in the Earth's Carbon Cycle, Berlin, Germany, 12-17 September 1993; Book of Abstracts. Zepp, R.G., Sonntag, S., Eds.; Wiley: New York, NY, USA, 1995; pp. 23-45.

72. Kaishan, S.; Li, L.; Tedesco, L.; Clercin, N.; Li, L.; Shi, K. Spectral characterization of colored dissolved organic matter for productive inland waters and its source analysis. Chin. Geogr. Sci. 2015, 25, 295-308.

73. Rasmussen, J.B.; Godbout, L.; Schallenberg, M. The humic content of lake water and its relationship to watershed and lake morphometry. Limnol. Oceanogr. 1989, 34, 1336-1343. [CrossRef]

74. D'Arcy, P.; Carignan, R. Influence of catchment topography on water chemistry in southeastern Quebec Shield lakes. Can. J. Fisher. Aquat. Sci. 1997, 54, 2215-2227. [CrossRef]

75. Chistov, S.V. Principles for determining environmental protection measures for the landscapes of the Western Siberian Arctic and Subarctic in conditions of economic development. In Problems of Ecology of Polar Regions; Nauka: Moscow, Russia, 1991; pp. 29-35.

76. Walker, D.A.; Leibman, M.O.; Epstein, H.E.; Forbes, B.C.; Bhatt, U.S.; Raynolds, M.K.; Comiso, J.C.; Gubarkov, A.A.; Khomutov, A.V.; Jia, G.J.; et al. Spatial and temporal patterns of greenness on the Yamal Peninsula, Russia: Interactions of ecological and social factors affecting the Arctic normalized difference vegetation index. Environ. Res. Lett. 2009, 4, 045004. [CrossRef]

77. Khomutov, A.V.; Khitun, O.V. The dynamics of vegetation cover and the depth of seasonal thawing in the typical tundra of Central Yamal under technogenic impact. TSU Gerald 2014, 4, 17-27. (In Russian)

78. Ukraintseva, N.G. Willow tundra in Yamal as the indicator of salinity of superficial sediments. In The Results of Fundamental Research of the Earth Cryosphere in Arctic and Subarctic; Nauka: Novosibirsk, Russia, 1997; pp. 173-182. (In Russian)

79. Muster, S.; Heim, B.; Abnizova, A.; Boike, J. Water body distributions across scales: A remote sensing based comparison of three Arctic tundra wetlands. Remote Sens. 2013, 5, 1498-1523. [CrossRef]

80. Muster, S.; Roth, K.; Langer, M.; Lange, S.; Aleina, F.C.; Bartsch, A.; Morgenstern, A.; Grosse, G.; Jones, B.; Sannel, A.B.K.; et al. PeRL: A Circum-Arctic Permafrost Region Pond and Lake Database. Earth Syst. Sci. Data 2017, 9, 317-348. [CrossRef]

81. Slonecker, E.T.; Jones, D.K.; Pellerin, B.A. The new Landsat 8 potential for remote sensing of colored dissolved organic matter (CDOM). Mar. Pollut, Bull. 2016, 107, 518-527. [CrossRef] [PubMed]

82. Kutser, T.; Tanvik, L.; Pierson, D.C. Variations in colored dissolved organic matter between boreal lakes studied by satellite remote sensing. J. Appl. Remote. Sens. 2009, 3, 033538.

83. Dvornikov, Y.; Leibman, M.; Heim, B.; Bartsch, A.; Haas, A.; Khomutov, A.; Gubarkov, A.; Mikhaylova, M.; Mullanurov, D.; Widhalm, B. Geodatabase and WebGIS project for long-term permafrost monitoring at the Vaskiny Dachi research station, Yamal, Russia. Polarforschung 2016, 85, 107-115. [CrossRef]

84. Cardille, J.A.; Leguet, J.-P.; del Giorgio, P. Remote sensing of lake CDOM using non-contemporaneous field data. Can. J. Remote Sens. 2013, 39, 119-126. [CrossRef]

(C) 2018 by the authors. Licensee MDPI, Basel, Switzerland. This article is an open access article distributed under the terms and conditions of the Creative Commons Attribution (CC BY) license (http://creativecommons.org/licenses/by/4.0/). 